\title{
Assessment of Ground water Quality in Mumbuni Estate, Machakos Town, Kenya
}

\author{
Julius Kioko Nzeve ${ }^{*}$, Grace Nduta Mbate \\ Department of Environmental Sciences, Machakos University, Machakos, Kenya \\ Email address: \\ jnzeve@gmail.com (J. K. Nzeve) \\ ${ }^{*}$ Corresponding author
}

To cite this article:

Julius Kioko Nzeve, Grace Nduta Mbate. Assessment of Ground water Quality in Mumbuni Estate, Machakos Town, Kenya. Journal of Health and Environmental Research. Vol. 7, No. 1, 2021, pp. 1-5. doi: 10.11648/j.jher.20210701.12

Received: January 11, 2021; Accepted: January 18, 2021; Published: January 28, 2021

\begin{abstract}
The rapid increase of global human population has led to more people living in towns and cities in the recent past. This has brought pressure on water service provision and sanitation infrastructure in many cities and towns including Machakos town. Due to surface water shortages, groundwater has been an alternative. This includes sinking of boreholes and hand dug shall wells. This study evaluated the concentration levels of physical and chemical parameters of water in selected boreholes and shallow wells in Mumbuni estate, Machakos town. A total of three boreholes and three shallow wells were included in the study. Water samples were collected in triplicates after every two weeks for a period of one and a half months from the selected sampling sites. The samples were transported to the Water Resources Authority (WRA) central laboratory in Nairobi for analysis using the standard methods for the examination of ground water. Independent T-test was used to analyze data and significance levels accepted at $\mathrm{p} \leq 0.05$. The results obtained were compared with both the World Health Organization (WHO) and Kenya Bureau of Standards (KEBS) drinking water standards in order to determine the quality of ground water and its suitability for drinking. All the parameters measured varied significantly between borehole water and shallow well water except for Calcium, Magnesium and potassium $(\mathrm{p} \geq 0.05)$. $\mathrm{pH}$, turbidity, electrical conductivity, Chloride, Fluoride and Sulphates were within the WHO and KEBS recommended limits for drinking water. Other parameters tested such as Calcium, Magnesium and Potassium were also within acceptable limits. The study concluded that water from boreholes and shallow wells in Mumbuni estate is suitable for drinking.
\end{abstract}

Keywords: Water Quality, Boreholes, Shallow Wells, Machakos Town

\section{Introduction}

Population growth in Sub Saharan Africa (SSA) urban areas has increased over the last 20 years at an average rate of $4 \%$ per annum which is away above the average global urban growth rate that range between $1.44 \%$ and $1.84 \%$ [1]. This has brought a lot of pressure on water service provision and sanitation infrastructure in cities and towns [2]. Water is important to all living things and without which life on earth would not exist. Access to safe drinking water and improved sanitation is a fundamental need and a human right which is vital for the dignity and health of all people. About 2.6 million people globally lack access to safe drinking water [3] and in SSA access to clean water for drinking stands at $23.7 \%$ as compared to $71 \%$ globally [4].
Human population has increased rapidly in Machakos town since the inception of devolved system of government in 2013. Machakos Water and Sewerage Company limited supplies Machakos town dwellers with treated piped water, however the supply has not been adequate due to the population surge and the infrastructural capital investments required. Therefore, rainwater harvesting and groundwater from boreholes and hand dug shallow wells have become alternative sources of drinking water. Groundwater is a very important resource for millions of people in the globe [5] and accounts for $26 \%$ of global renewable freshwater resources [6]. Groundwater is the major source of drinking water in Africa [7] and its use is increasing due to population increase and search for climate resilient water supplies [8]. The quality of water from some of these alternative sources have a direct effect on the health of individuals [9] and thus calling 
for water quality assessment. Ground water quality includes the physical, chemical and biotic characteristics of ground water. Poor ground water quality usually results from elevated naturally occurring harmful elements such as fluoride, iron and heavy metals among others. The residents of Mumbuni estate, in Machakos town use ground water from boreholes and hand dug shallow wells as alternative sources of water for domestic use since the water table is high. Most of boreholes have been drilled by entrepreneurs who sell the water to the urban dwellers. Shallow wells are mostly used by the owners within a homestead. The estate is not connected to the main municipal sewerage treatment system. The residents use septic tanks and pit latrines and this increases the risks of groundwater contamination that may affect human health. This study analyzed the quality of groundwater in Mumbuni estate to determine its suitability for drinking based on set standards by World Health Organization (WHO) and Kenya Bureau of Standards (KEBS).

\section{Materials and Methods}

\subsection{Study Area}

The study was conducted in Mumbuni estate located along Machakos- Kangundo road, about 3 kilometers away from Machakos town centre, in Machakos County. The size of the Mumbuni location covers approximately $30.50 \mathrm{~km}^{2}$ and is located at an elevation of 1,214 meters above sea level. Mumbuni ward has a population of approximately 49,802 residents. The population is increasing rapidly due to favorable climatic conditions and urbanization.

\subsection{Water Sampling and Laboratory Analysis}

Purposive sampling was used to select boreholes and hand dug shallow wells that were included in the study. The boreholes were selected based on the number of people drawing water from them while, the shallow wells were selected based on owner's willingness to give out water samples. A total of three boreholes $(\mathrm{BH} 1, \mathrm{BH} 2 \& \mathrm{BH} 3)$ and three shallow wells (SW1, SW2 \&SW3) were included in the study. Water samples were collected in triplicates from the selected sampling sites. Pre- washed polyethylene bottles $(500 \mathrm{ml})$ and rinsed with $10 \%$ nitric acid were used to collect water samples from the selected sampling sites. The sample bottles were rinsed thrice with the sample water before the actual sample was taken. The sample bottles were then labelled and stored in iced cool box. The water samples were collected after every two weeks for a period of one and a half months. The samples were transported to the Water Resources Authority (WRA) central laboratory in Nairobi for analysis using the standard methods for the examination of ground water. $\mathrm{pH}$, turbidity, Electrical conductivity (EC) were measured using standard meters, while Calcium $(\mathrm{Ca})$ and Magnesium (Mg) were determined by volumetric titration method. Chlorides $\left(\mathrm{Cl}^{-}\right)$was determined by titration method using silver nitrate, potassium chromate and Fluoride
$\left(\mathrm{F}^{-}\right)$by Selective Electrode Method. Sulphates $\left(\mathrm{SO}_{4}{ }^{2+}\right)$ was determined by turbidimetric method and Potassium $(\mathrm{K})$ by Flame Photometry.

\subsection{Data Analysis}

Independent T-test was used to analyze data and significance levels accepted at $\mathrm{p} \leq 0.05$. Where significant differences were obtained further analysis using Post Hoc Tukey test was carried out to separate the means. All the analysis was done using IBM SPSS version 21. The results obtained were compared with both the WHO and KEBS drinking water standards in order to determine the quality of ground water and its suitability for drinking.

\section{Results and Discussions}

The physico-chemical parameters of ground water measured are presented in Table 1. Additionally, the mean values of water quality parameters measured for each sampling site are shown in Table 2 and Figure 1.

\section{1. $\mathrm{pH}$}

$\mathrm{pH}$ shows the strength of water to react with acidic or alkaline materials. In this study the mean $\mathrm{pH}$ values were $7.922 \pm 0.124$ and $7.106 \pm 0.170$ for the shallow wells and boreholes respectively. There was a significant difference between the mean $\mathrm{pH}$ values for shallow wells and boreholes $(\mathrm{p} \leq 0.05)$. The mean $\mathrm{pH}$ values for each sampling site are presented in table 2 . The $\mathrm{pH}$ values for all the boreholes and shallow wells sampled were within the WHO and KEBS recommended limits of 6.5-8.5 and thus suitable for drinking. However, all the shallow wells were slightly more alkaline compared to the borehole water.

\subsection{Turbidity}

The mean turbidity vale for shallow wells was $4.868 \pm 5.039$ NTUs compared to $0.651 \pm 0.333$ NTUs for boreholes. Significant difference was noted for the turbidity levels of shallow wells and boreholes $(p=0.023)$. Except SW3, all the other shallow wells and boreholes had turbidity values within the WHO guidelines and KEBS set limits for drinking water as shown in table 2. The occurrence of suspended soils, sediment, carbon-based substance, inorganic material and other invisible living things enhances turbidity. The level of turbidity shows just a suggestion of the degree of pollution [10].

\subsection{Electrical Conductivity}

The conductivity values were $784.667 \pm 141.667 \mu \mathrm{s} / \mathrm{cm}$ and $573.889 \pm 177.828 \mu \mathrm{s} / \mathrm{cm}$ for shallow wells and boreholes respectively. The electrical conductivity was below the WHO and KEBS standard value thus suitable for drinking. The conductivity values exhibited significant differences between the shallow wells and boreholes $(p=0.013)$. Electrical conductivity is linked to the quantity of cations and anions in the water. 
Table 1. Comparison of physicochemical parameters measured against WHO and KEBS standards.

\begin{tabular}{llllll}
\hline Source of water/Parameter & Shallow wells & Boreholes & P value & WHO Standards [11] & KEBS Standards [12] \\
\hline $\mathrm{pH}$ & $7.922 \pm 0.124$ & $7.106 \pm 0.170$ & 0.0001 & $6.5-8.5$ & $6.5-8.5$ \\
Turbidity $(\mathrm{NTU})$ & $4.868 \pm 5.039$ & $0.651 \pm 0.333$ & 0.023 & 5 & 5 \\
Conductivity $(\mu \mathrm{s} / \mathrm{cm})$ & $784.667 \pm 141.667$ & $573.889 \pm 177.828$ & 0.013 & 2500 & - \\
Fluoride $(\mathrm{mg} / \mathrm{L})$ & $0.252 \pm 0.029$ & $0.214 \pm 0.031$ & 0.019 & 1.5 & 1.5 \\
Chloride $(\mathrm{mg} / \mathrm{L})$ & $174.667 \pm 19.041$ & $92.889 \pm 48.945$ & 0.0001 & 250 & 250 \\
Sulphates $(\mathrm{mg} / \mathrm{L})$ & $4.240 \pm 1.089$ & $16.939 \pm 13.431$ & 0.012 & 450 & 400 \\
Potassium $(\mathrm{mg} / \mathrm{L})$ & $5.011 \pm 1.266$ & $6.311 \pm 2.588$ & 0.195 & 50 & 100 \\
Magnesium $(\mathrm{mg} / \mathrm{L})$ & $27.411 \pm 8.449$ & $21.216 \pm 3.626$ & 0.060 & 100 & 150 \\
Calcium $(\mathrm{mg} / \mathrm{L})$ & $56.945 \pm 18.622$ & $44.144 \pm 12.719$ & 0.108 & 100 & \\
\hline
\end{tabular}

\subsection{Fluoride}

Fluoride at low concentrations is beneficial to dental health and is usually added to water supplies and dental products but cognizant that high concentrations is detrimental to human health [13]. Fluoride levels were very low at $0.252 \pm 0.029 \mathrm{mg} / \mathrm{L}$ for wells and $0.214 \pm 0.031 \mathrm{mg} / \mathrm{L}$ for boreholes (Table 1) and the mean values for each sampling site are presented in Figure 1. When Fluoride occurs in low levels of 0.8 to $1.0 \mathrm{mg} / \mathrm{L}$ it is of essence for fortifying of tooth surface. If taken in persistent amounts of over $1.2 \mathrm{mg} / \mathrm{L}$ leads to tooth fluorosis [14]. Fluoride arises from groundwater dissolution in fluoride-rich lithologies, including clay minerals and micas, biotite metamorphic basement rocks and basement volcanic rocks of alkaline composition [15-17]. In this study, samples analyzed indicated low levels of Fluoride which were all under the standard limits required of $1.5 \mathrm{mg} / \mathrm{L}$ meaning that it is suitable for drinking even though there is significant difference between the wells and the boreholes.

\subsection{Chloride}

The mean chloride values were $174.667 \pm 19.040 \mathrm{mg} / \mathrm{L}$ and $92.889 \pm 48.945 \mathrm{mg} / \mathrm{L}$ for shallow wells and boreholes respectively. There was significant difference between the wells and boreholes, $(\mathrm{p} \leq 0.05)$ as shown in Table 1 and Figure 1. There was variation due to difference in soils, rocks and their permeability. Chloride originates from water-soluble chloride salts present in minerals and is vital for metabolism activity in human body and other important physiological processes $[18,19]$. Weathering and leaching of domestic and agricultural effluents can be a source of chloride in water [20]. Chloride level is increased in ground water where rainfall is low and heat level is high. Soil permeability and absorbency also plays a major part in building the chloride concentration [21]. Fertilizer and vegetable nutrient use usually lead to increased levels of chlorides. In this study area, low concentration of chlorides was less than $250 \mathrm{mg} / \mathrm{L}$, the WHO set limit for drinking water. Therefore, the quality of sampled water was found good for drinking.

Table 2. Mean $p H$, turbidity and electrical conductivity for each sampling site.

\begin{tabular}{lllllll}
\hline Sampling site/Parameter & SW1 & SW2 & SW3 & BH1 & BH2 & BH3 \\
\hline $\mathrm{pH}$ & $8.063 \pm 0.045$ & $7.917 \pm 0.042$ & $7.787 \pm 0.015$ & $7.303 \pm 0.162$ & $6.997 \pm 0.015$ & $7.017 \pm 0.031$ \\
Turbidity $(\mathrm{NTU})$ & $0.977 \pm 0.042$ & $2.073 \pm 0.118$ & $11.553 \pm 0.328$ & $0.477 \pm 0.108$ & $0.393 \pm 0.040$ & $1.083 \pm 0.064$ \\
Conductivity $(\mu \mathrm{s} / \mathrm{cm})$ & $775.667 \pm 3.055$ & $951.333 \pm 26.558$ & $627.00 \pm 22.068$ & $809.000 \pm 3.606$ & $431.000 \pm 9.849$ & $481.667 \pm 9.074$ \\
\hline
\end{tabular}

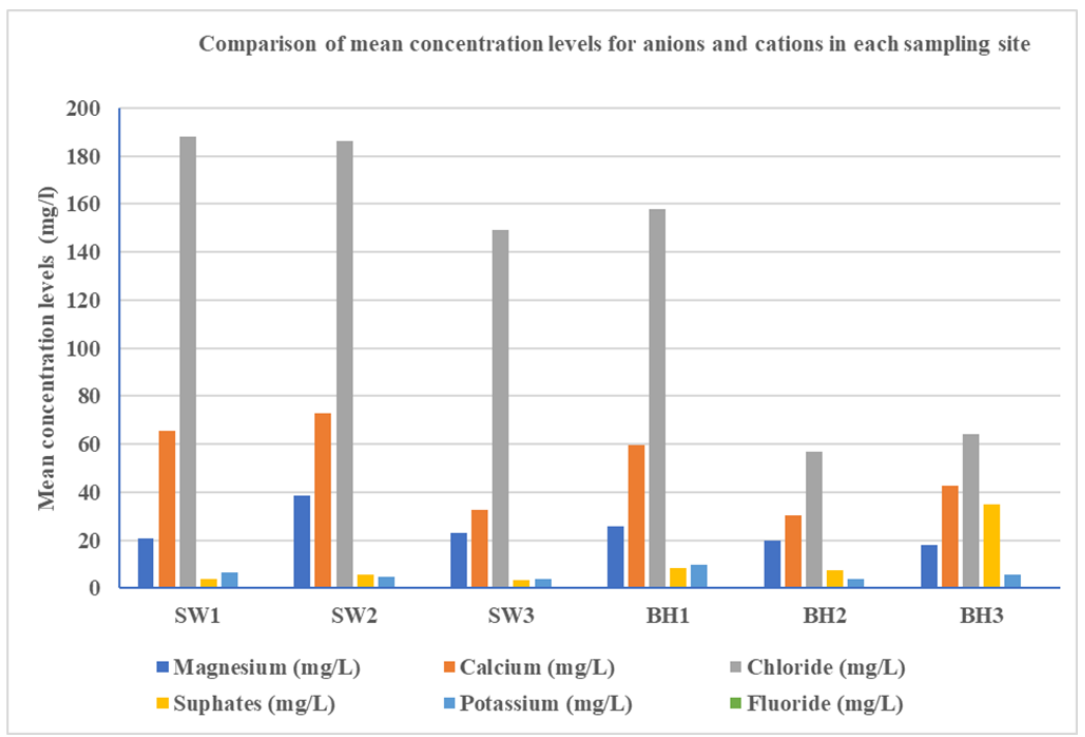

Figure 1. Mean Concentration levels for anions and cations in each sampling site. 


\subsection{Calcium}

The Calcium mean values measured were $56.945 \pm 18.622 \mathrm{mg} / \mathrm{L}$ and $44.144 \pm 12.719 \mathrm{mg} / \mathrm{L}$ for the shallow wells and boreholes respectively. The difference of Calcium concentration between boreholes and wells was not significant. Natural water contains a reasonable quantity of calcium and adequate intake is usually essential for normal growth and good health [22] while low concentrations in drinking water can lead to defective teeth, poor blood clotting, borne fracture and rickets [19]. However, high concentration of calcium ions causes abdominal ailments, encrustation and scaling [23]. The levels of Calcium hardness in this study were below the WHO acceptable standards of $100 \mathrm{mg} / \mathrm{L}$ as indicated in Tables 1 and 2. The total hardness of water is increased by Calcium and is a vital micro-nutrient in water.

\subsection{Magnesium}

The Magnesium mean concentration levels obtained were $27.411 \pm 8.449 \mathrm{mg} / \mathrm{L}$ for shall wells and $21.216 \pm 3.626 \mathrm{mg} / \mathrm{L}$ boreholes and showed no significant difference $(p=0.06)$. Magnesium ions just like Calcium ions are a major cause of hardness. The total of Calcium and Magnesium concentrations describe total hardness of water. From the findings, Magnesium ions were present but not in very high concentrations hence the quality of the ground water is good for drinking purposes. Magnesium concentration levels were found to be below $100 \mathrm{mg} / \mathrm{L}$ indicating that they are within WHO and KEBS acceptable levels for drinking water.

\subsection{Sulphates}

The sulphates concentration levels obtained were $4.240 \pm 1.089 \mathrm{mg} / \mathrm{L}$ and $16.939 \pm 13.431 \mathrm{mg} / \mathrm{L}$ for shallow wells and boreholes respectively. The most common form of sulphur in well aerated water is sulphate. Significant difference was found between wells and boreholes due to the variation of dissolved solids. The analyzed samples were all below the required levels according to WHO set standards [11] hence suitable for drinking.

\subsection{Potassium}

The potassium mean values were $5.011 \pm 1.266 \mathrm{mg} / \mathrm{L}$ for the shallow wells and $6.311 \pm 2.588 \mathrm{mg} / \mathrm{L}$ for boreholes. No significant difference was found to be between shallow wells and boreholes. Potassium concentration was found to be below the maximum permissible levels therefore suitable for drinking purposes in the study area. The likely sources of potassium in groundwater are silicate minerals and igneous and metamorphic rocks. High potassium concentrations occur in ground water of urban areas due to sewage infiltration.

\section{Conclusion and Recommendations}

All the water quality parameters measured were within acceptable WHO and KEBS set standards and therefore concluded that the quality of groundwater in Mumbuni estate is suitable for drinking. However, as more boreholes and shallow wells are dug to meet the high demand for drinking water, the county government of Machakos should ensure regular monitoring of groundwater to ensure its within required standards for human consumption. Since this study only focused on physico-chemical parameters, there is need for further research to assess the level of microbial contamination of water from the shallow wells and boreholes in Mumbuni estate.

\section{Acknowledgements}

The authors are indebted to the Water Resources Authority central laboratory in Nairobi for accepting the use of their laboratory during analysis of water samples.

\section{References}

[1] White, R., Turpie, J., Gwyneth, L. (2016). Greening Africa's Cities: Enhancing the Relationship between Urbanization, Environmental Assets and Ecosystem Services; World Bank: Washington, DC, USA, 2016; pp. 1-73.

[2] Nyilitya, B., Mureithi, M. S., Boeckx, P. (2020). Tracking Sources and Fate of Groundwater Nitrate in Kisumu City and Kano plains, Kenya. Water 2020, 12, 401; doi: 10.3390/w12020401.

[3] Nyagwencha, J. M., Kaluli, J. W., Home, P. G. and Murage, H. (2017) Access to Safe Drinking Water and Water-Borne Diseases in Masaba North District, Kenya. JKUAT Annual Scientific Conference, Nairobi, 688-694. http://journals.jkuat.ac.ke/index.php/jscp\%0Ahttp://hdl.handle .net/123456789/2882.

[4] United Nations (2018). The Sustainable Development Goals Report 2018; United Nations: New York, NY, USA, 2018.

[5] Ghalib, H. B (2017). Groundwater chemistry evaluation for drinking and irrigation utilities in east Wasit province, Central Iraq. Appl Water Sci 7: 3447-67. doi: 10.1007/s13201-0170575-8.

[6] Elbeih, S. F (2015). An overview of integrated remote sensing and GIS for groundwater mapping in Egypt. Ain Shams Eng $J$ 2015; 6 (1): 1-15.

[7] Gaye, C. B and Tindimugaya, C (2019). Challenges and opportunities for sustainable groundwater management in Africa Hydrogeol. J. 27 1099-110.

[8] Howard, G., Calow, R., Macdonald, A and Bartram, J (2016). Climate change and water and sanitation: likely impacts and emerging trends for action Annu. Rev. Environ. Resour. 41 253-76.

[9] WHO (2002). Managing Water in the Home: Accelerated Health Gains from Improved Water Supply. Geneva: World Health Organization, Document No. WHO/SDE/WDE/WSH/02. Available: http://www.who.int/phe. 
[10] Momba, M. N. B., Tyafa, Z., Makala, N., Brouckaert, B. N and Obi, C. L (2006). Safe drinking water still a dream in rural areas of South Africa. Case Study: The Eastern Cape Province. Water Institute of South Africa (WISA) Biennial Conference, Durban, South Africa, 21-25 May 2006.

[11] WHO (2017). Guidelines for Drinking-Water Quality: Fourth Edition Incorporating the First Addendum; WHO Guidelines Approved by the Guidelines Review Committee, World Health Organization: Geneva, Switzerland, 2017.

[12] KEBS (2007). Drinking water specification. Part 1: the requirements for drinking water. In Water, 3rd Edition; Kenya Bureau of Standards, Nairobi, Kenya 2007.

[13] Edmunds, M and Smedley, P. M (2013). Fluoride in natural waters. Essentials of Medical Geology 2, 311-336.

[14] DenBesten, P and Li, W (2011). Chronic fluoride toxicity: dental fluorosis. Monogr Oral Sco 22, 81-96.

[15] Mapoma, H. W. T. M., Xie, X., Liu, Y., Zhu, Y., Kawaye, F. P and Kayira, T. M (2017). Hydrochemistry and quality of groundwater in alluvial aquifer of Karonga, Malawi. Environ. Earth Sci. 76 (9), 335.

[16] Battaleb-Looie, S., Moore, F., Jacks, G., and Ketabdari, M. R (2012). Geological sources of fluoride and acceptable intake of fluoride in an endemic fluorosis area, southern Iran. Environ. Geochem. Health 34 (5), 641-650.

[17] Ghiglieri, G., Pittalis, D., Cerri, G., and Oggiano, G (2012). Hydrogeology and hydro geochemistry of an alkaline volcanic area: the NE Mt. Meru slope (East African Rift - Northern Tanzania). Hydrol. Earth Syst. Sci. 16, 529-541.

[18] Tirkey, P., Bhattacharya, T., Chakraborty, S., and Baraik, S. (2017). Assessment of groundwater quality and associated health risks: a case study of Ranchi city, Jharkhand, India. Groundwater Sustainable Dev 2017; 5: 85-100.

[19] Meride, Y and Ayenew, B (2016). Drinking water quality assessment and its effects on residents' health in Wondo genet campus, Ethiopia. Environ Syst Res 2016; 5 (1): 1.

[20] Kawo, N. S and Karuppannan, S. (2018). Groundwater quality assessment using water quality index and GIS technique in Modjo River Basin, central Ethiopia. J Afr Earth Sc 2018; 147: $300-11$

[21] Ramakrishnaiah C. R., Sadashivaiah, C. and Ranganna, G. (2009). Assessment of Water Quality Index for the Groundwater in Tumkur Taluk, Karnataka State, India, EJournal of Chemistry, 6 (2), 523-530.

[22] Isah. M. A., Harir. O., Chiroma, M. A., and Umaru, A (2015). Parameters of water quality in hand dug wells (HDW) from hardo ward, bauchi metropolis, Nigeria. ARPN J Eng Appl Sci 2015; 10 (16): 6804-10.

[23] Logeshkumaran, A., Magesh, N., Godson. P. S., and Chandrasekar, N (2015). Hydrogeochemistry and application of water quality index (WQI) for groundwater quality assessment, Anna Nagar, part of Chennai City, Tamil Nadu, India. Appl Water Sci 2015; 5 (4): 335-43. 